\title{
MARCO POLO IN THE DIGITAL ENVIRONMENT OF SERBIAN ACADEMIC LIBRARIANSHIP
}

Summary: Venitian and Korčula spirit of Marco Polo as well as his curiousity are present in the central library of The University of Belgrade since it was open. Since 1926 students enter, pass and enjoy reading travel novels, professional and scientific literature in several languages tending to finish their studies in time with the best possible result. Almost every student is interested in the possibility to travel abroad for affairs upon the finalization of his studies.

The scope of this paper is to present the materials on Marco Polo in the academic librarianship of Serbia but also in its' digital environment. The theoretical framework of this paper is library and information one. The method used is the empirical one with a statistical approach.

This paper is written having in mind those libraries which are included into COBISS.SR (Cooperative On-line Bibliograhic System \& Services. Serbia). The structure of collections in Serbian academic librarianship will be described having in mind this famous personnality who left a deep trace in the culture and civilization of Europe changing its' views particularly on Far East. Due to the fact that we all live in the Age of Open Science, texts on Marco Polo become closer to readers interested in cultural and economic history who are ready to get concentrated on travel writings and other similar materials. Life in a Society 3.0 requires certain skills, particularly in the case of readers who would like to know more and explore those materials which refer to their domain stimulated by a desire to prepare their own written paper as well as an exposé in a very argumented way. Serbian academic librarianship should help them to achieve it.

Keywords: Marco Polo, Serbia, academic librarianship, digitization, environment, collections, bibliographic descriptions.

\section{INTRODUCTION}

Marko Polo was born in Dalmatia in 1254. His father and uncle were from an old Korčulan family. They were going in for trade and shipbuilding. Some members of that old family were working as security on the island of 
Korčula. Marko's father Niccolo and Marko's uncle Matteo9, two brothers hardly separable were travelling from Korčula to Constantinople where they were going in for trade and shipbuilding. The origins of the family Polo-DePolo was from Korčula where its members were living during several centuries.

Josip Šarac alleged that the first resource which emphasized the Dalmatian origin of Marko Polo and which documented that he was from Dalmatia was a big chronicle on the history of Venice from its beginnings until $1446^{10}$. That Chronicle contains 618 pages $^{11}$.

The father and uncle of Marko Polo, two noblemen were travelling often. Therefore they were not following the meetings of noblemen that were being organized twice a year. As Marko's father bought a house in Venice later on, it was clear that his travellings were planned with a scope to earn money. The title of a nobleman was insufficient to bring him a financial inflow. Therefore the two brothers left the island of Korčula relying on their own knowledge and experience in trade and shipbuilding led by their whish to create themselves conditions for a more confortable life. Brothers Polo had an entrepreneurial spirit. They were very penetrable and capable men who were having in mind during all their travellings that Marko lost his mother very early, in fact - as a baby.

Marco Polo, his father and uncle were travelling towards Asia and realizing a vivid diplomatic activity. It is in a battle between Genoa and Venice in 1298 that Venice had to withdraw itself. So, Marco Polo who was a warior on the side of Venice got captured. He probably did not expect that when he decided to go to that battle. It is in the prison that he wrote his famous work "Livre des merveilles du monde» which was published in French.

Marco Polo died in 1324. He stayed remembered as a world traveller, a great adventurer, encyclopedist, financist, and a talented writer as well. This famous travel writer had opened a gate of Far East to the European civilization. The inhabitants of Korčula keep talking on Marco Polo with warm devotion tending to describe the period of his travellings in the best possible way. Although Marco Polo was the merchant of Venice, he was born on the island of Korčula and his father was Croatian. Croatian origin was leading Marco towards Korčula where the interests of Genoa and Venice had been in a deep

9 Ivan Peklić, Marko Polo - svjetski putnik, Metodički ogledi, 17 (2010), br. 1-2, str. 50. Dostupno na: https://hrcak.srce.hr/file/102233 (Pristup: 15. mart 2019)

10 Josip Šparac, Dokumenti o Korčulaninu Marku Polu, Turistički biro i Turističko društvo Korčula, 1971, str. 25.

11 Arnoldo Bacotich, "Tribuni antichi di Venezia di origine dalmata". U: Archivio storico per la Dalmazia”, 1938, Vol. XXV. 
coflict. Marko was able to lead business books and therefore he was able also to earn during the period of his professional work for Kublai Khan.

\section{MARCO POLO IN THE ACADEMIC LIBRARIANSHIP OF SERBIA}

If somebody would retrieve the cumulative e-catalogue COBIB.SR he would notice why the chart no. 1 in this article looks as on this same picture. So, there are materials on Marco Polo in the academic librarianship of Serbia mostly in Serbian and in English if we talk on references in world languages. Library materials are being classificated according to UDC (Universal Decimal Classification). It is obvious from e-catalogues in the system COBISS.SR (Cooperative On-line Bibliographic System \& Services. Serbia). That system is created in collaboration with The Institute of Information Sciences IZUM in Maribor ${ }^{12}$. All the materials in those libraries which belong to the system COBISS.SR are being catalogued and classificated de visu and in accordance with International Standards for Bibliographic Description of library materials adopted by IFLA (International Federation of Library Associations and Institutions $)^{13}$.

Chart 1. The no. of bibliographic descriptions on Marco Polo in the cumulative e-catalogue COBIB.SR

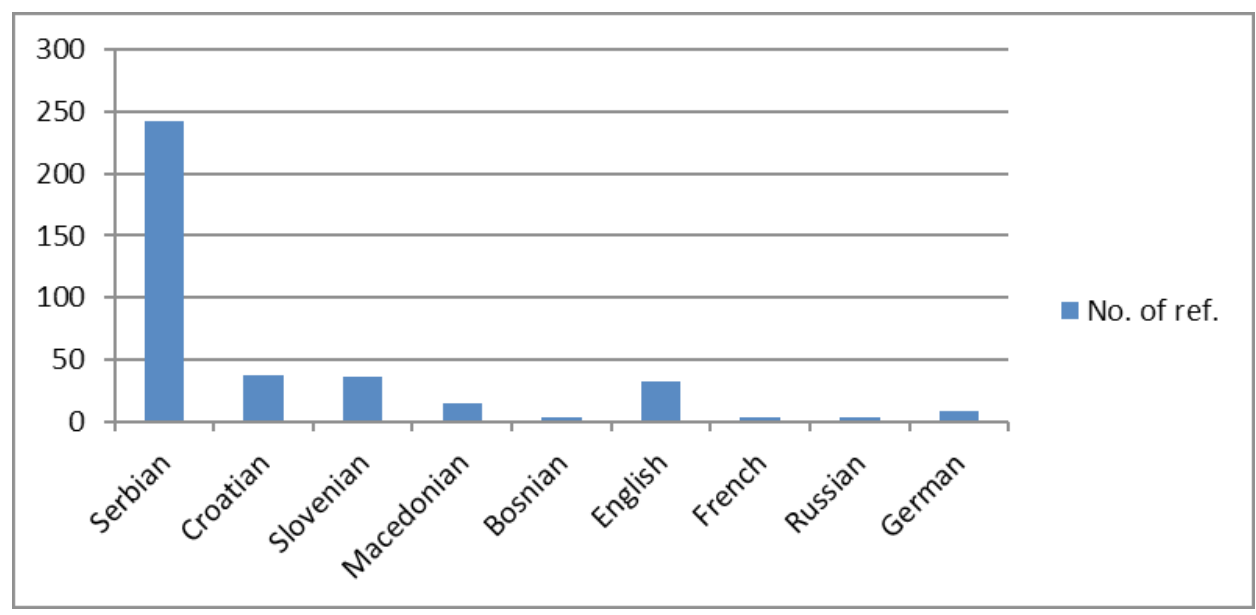

Resource for data: cumulative e-catalogue COBIB.SR (Access: 10. March 2019)

12 www.izum.si (Access: 12. March 2019)

13 www.ifla.org (Access: 15. March 2019) 
This paper doesn't comment the quality of the acquired library materials. Every library acquires materials in accordance with its own type. If there is a lack of needed materials, library users may search e-journals with e-articles in full text. Except that, an interlibrary loan service with abroad is a way to compensate for the lack of literature. The central library of The University of Belgrade e.g. The "Svetozar Marković" University Library has an interlib- rary loan service with abroad in its range of services for library members. ${ }^{14}$ This way books as well as articles can be ordered from foreign libraries.

Chart 2 Bibliographic descriptions of materials on Marco Polo in the academic librarianship of Serbia

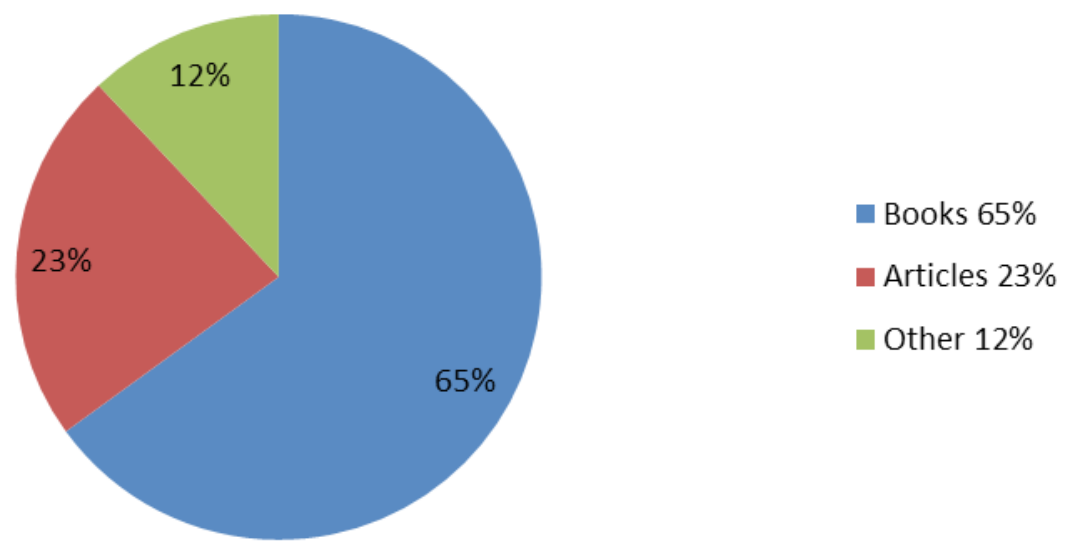

Resource: cumulative e-catalogue COBIB.SR (Access: 10. March 2019)

Chart 2 shows the structure of literature on Marco Polo in the academic librarianship of Serbia having in mind all the bibliographic descriptions on him which were received due to the retrieval of the cumulative e-catalogue COBIB.SR. So, according to the results of such a retrieval there are $65 \%$ of books on Marco Polo and 23\% of articles. Other forms of works on Marco Polo cover $12 \%$ out of the total number of library units on Marco Polo whose bibliographic descriptions were found in COBIB.SR.

This great researcher - Marco Polo was using continental roads and sailing streams to reach his scope. The Silk Road consisted of the whole net of continental and sailing roads which were connecting Europe with Far East. The travelling of Marco Polo overlapped with one part, one segment of The Silk Road which was known in that period.

14 www.unilib.rs (Access: 9. March 2019) 
Map 1. The travelling of Marco Polo

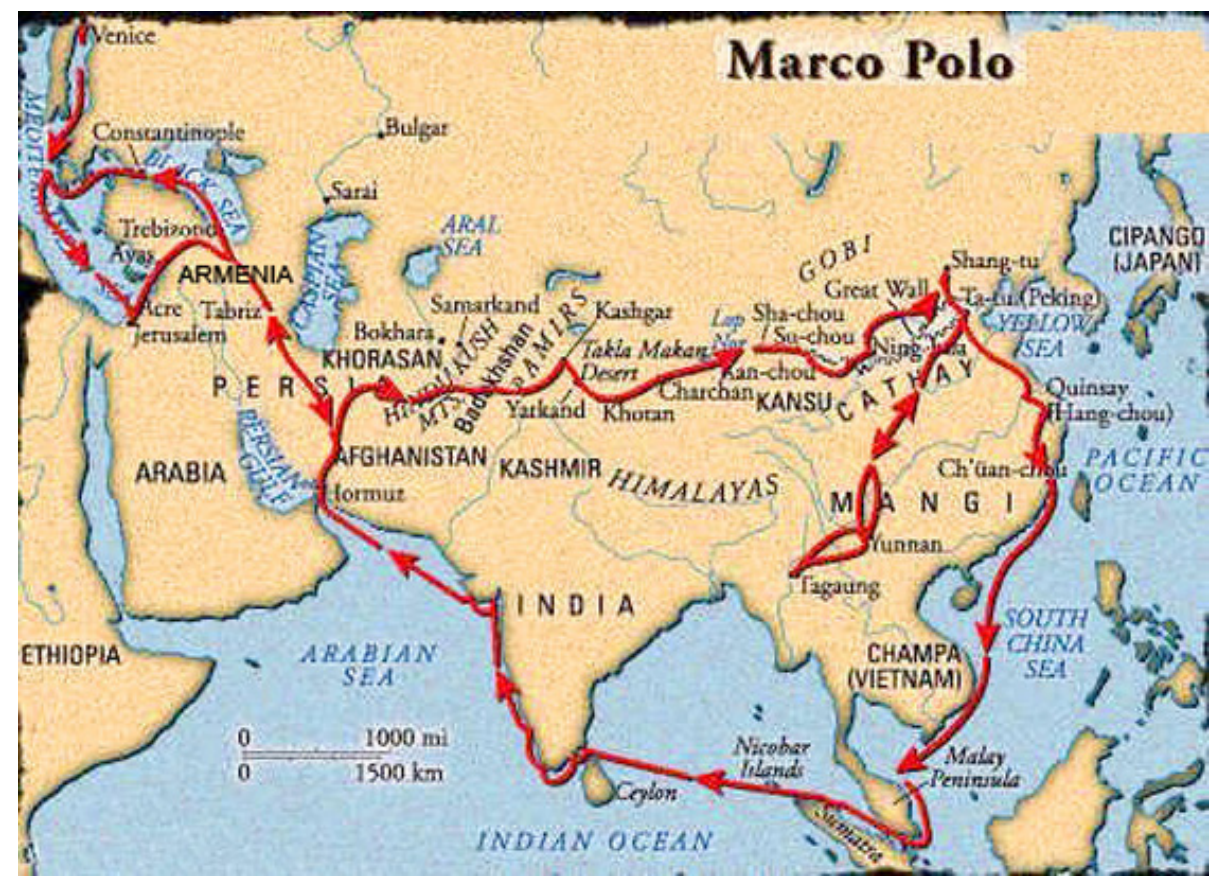

Resource: https://marcopolovoyage.weebly.com/ (Access: 10. March 2019)

Map 1 shows clearly the way Marco Polo was using with his father and uncle. During the period of Marco's life, America was unknown to the Europeans. Marko was working very long for famous Kublai Khan in the domain of collecting taxes.

One of the ways to get more familiar with The Silk Road is to consult the materials in free access. E-theses on The Silk Road can be found in full text on the European Portal of E-theses DART. Table 1 illustrates the situation on this very Portal.

So, the number of theses defended on The Silk Road is low. The highest number of theses was defended in Italy e.g. five theses in this case. Two theses were defended in France, in Netherlands also two but only one in Germany as well as in Sweden. 
Table 1. Theses on The Silk Road defended in Europe

\begin{tabular}{|l|l|}
\hline State & No. of e-theses \\
\hline Italy & 5 \\
\hline France & 2 \\
\hline Netherlands & 2 \\
\hline Germany & 1 \\
\hline Sweden & 1 \\
\hline Total & 11 \\
\hline
\end{tabular}

Source: European Portal of E-theses DART accessed 10 March 2019.

Several beneficial web addresses are quoted below. They are practical for finding full texts refering to Marco Polo's travellings to Far East and his vision of the entire regions that he was describing. These web addresses are:

https://archive.org/stream/marcopolo00 polou oft/ marcopolo00polouoft_djvu.txt

https://www.fulltextarchive.com/pdfs/The-Travels-of-Marco-PoloVolume-2.pdf

http://www.gutenberg.org/ebooks/10636

It is due to these addresses that full texts can be found freely available on Internet. So, there is no need for username or password.

\section{CONCLUSION}

Marko Polo lives due to his travel writings and works on him. The academic librarianship of Serbia gives users the opportunity to consult and read literature on Marco Polo. The majority of works on Marco Polo is published in Serbian, Croatian, Slovenian and in English, less in German. Bibliographic descriptions of works are being done in accordance with International Standards for Bibliographic Descriptions of library materials. The classification of these works is being done according to UDC e. g. Universal Decimal Classification as well as for all other library materials in the academic librarianship of Serbia.

It is on the European Portal of E-theses DART that full texts on The Silk Road can be found. The theses from this Portal are in free access. Although the first idea was that the theses defended in Europe should be in free access there are always certain exceptions. The law on the protection of intellectual property or a similar one differs from one state to another. 
The lack of literature can be compensated by the retrieval of e-journals with e-articles in full text. Except that, there is a possibility to use an interlibrary loan service with abroad. The central library of The University of Belgrade offers this possibility to its readers. Besides, the users rely on the interlibrary loan service with abroad whenever they need a printed material for their studies or research.

\section{Resources}

Ivan Peklić, Marko Polo - svjetski putnik, Metodički ogledi, 17 (2010), br. 1-2, str. 49-60. Available at: https://hrcak.srce.hr/file/102233

Josip Šarac, Dokumenti o Korčulaninu Marku Polu, Turistički biro i Turističko društvo Korčula, 1971, str. 25.

Arnoldo Bacotich, Tribuni antichi di Venezia di origine dalmata. U: Archivio storico per la Dalmazia, 1938, Vol. XXV. www.unilib.rs (Access: March 2019) www.nb.rs (Access: March 2019) www.dart-europe.eu (Access: March 2019) www.izum.si (Access: March 2019) https://archive.org/stream/marcopolo00polouoft/marcopolo00polouoft_djvu.txt (Access: March 2019)

https://www.fulltextarchive.com/pdfs/The-Travels-of-Marco-Polo-Volume-2.pdf (Access: March 2019)

http://www.gutenberg.org/ebooks/10636 (Access: March 2019)

https://marcopolovoyage.weebly.com/ (Access: March 2019) 


\section{Весна Жупан}

Универзитетска библиотека

„Светозар Марковић“

Београд

\section{МАРКО ПОЛО У ДИГИТАЛНОМ ОКРУЖЕЊУ АКАДЕМСКОГ БИБЛИОТЕКАРСТВА СРБИЈЕ}

Сажетак: Венецијанско-корчулански дух Марка Пола као и његова знатижеља присутни су у централној библиотеци Универзитета у Београду веома дуго. Од 1926. студенти улазе, пролазе и уживају читајући разне пустоловне романе, стручну и научну литературу на више језика, а настојећи да студије заврше на време са што бољим успехом. Такорећи сваки студент је заинтересован за могућност да путује у иностранство по окончању својих студија.

Овај рад има за циљ да представи присуство грађе о Марку Полу у академском библиотекарству Србије али и у његовом дигиталном окружењу. Теоријски оквир рада је, дакле, библиотечко-информациони. Коришћени метод је емпиријски, а приступ је статистички.

Рад је написан имајући на уму оне библиотеке које су укључене у COBISS. SR (Кооперативни он-лајн библиографски систем \& сервиси. Србија). Структура фондова академског библиотекарства Србије биће описана, а имајући у виду ову знамениту личност која је оставила дубок траг у култури и цивилизацији Европе изменивши знатно њену представу, нарочито - о Далеком Истоку. Захваљујући томе што живимо сви у Доба отворене науке, текстови о Марку Полу постају све ближи читаоцима заинтересованим за културну и економску историју, који су спремни да се усредсреде на путописе и њима сродну грађу. Живети у Друштву 3.0 изискује и одређене вештине, нарочито код читалаца који желе да сазнају више, истраже добро грађу о некоме или нечему, а подстакнути жељом да свој писани рад и излагање припреме на веома аргументован начин. Академско библиотекарство Србије треба да им помогне да то постигну.

Кључне речи: Марко Поло, Србија, академско библиотекарство, дигитализација, окружење, фондови, библиографски описи. 